\title{
BEGINNINGS AND DEVELOPMENT OF RUGBY IN UKRAINE
}

\author{
Ivashchenko Sergii \\ Borys Grinchenko Kyiv University, Kyiv, Ukraine
}

UDK 793/799:796.333(477.7)

\section{SUMMARY}

The founder of rugby as a specific kind of sport in Ukraine was Odessa. In 1878, the Odessa British Athletic Club was founded in South Palmyra, which was assembled by the British - employees of commercial firms, shipping companies, as well as employees of the Indo-European telegraph.

Keywords: history, rugby, Ukraine

\section{Corresponding author}

Ivashchenko Sergii

algis6274@hotmail.com

The history of rugby in Ukraine was atypical in comparison with other countries in the world. This is due to the features of the historical process of development of Ukraine as an independent state.

The founder of rugby as a specific kind of sport in Ukraine was Odessa. In 1878, the Odessa British Athletic Club was founded in South Palmyra, which was assembled by the British - employees of commercial firms, shipping companies, as well as employees of the Indo-European telegraph.

"A lot of foreign steamers called at the Odessa port. Once a ship of an English company landed on the beach. The team of this ship called the inhabitants of Odessa to play rugby. For us it was a new game, but we all agreed, and the meeting took place. The match was harsh, rude in nature: for example, a ship cook grabbed my leg while I was racing with an oval ball to the front line. Of course, I fell, but did not let the ball out of my hands. A fight was fought over me, in which everyone tried to knock down the opponent and take possession of the ball, "is an excerpt 
from the memoirs of Lieutenant General M.M. Biyazi, then still a student of one of the Odessa gymnasiums. However, this is more a legend than documentary truth.

The first official rugby match in modern Ukraine took place on July 9, 1922. Two teams entered the field of the sports club in Lvov: White Eagle (consisting of Polish and local rugby players) and Black Eagle (consisting of French players). The meeting ended with the victory of the "blacks" with a score of 6: 3 .

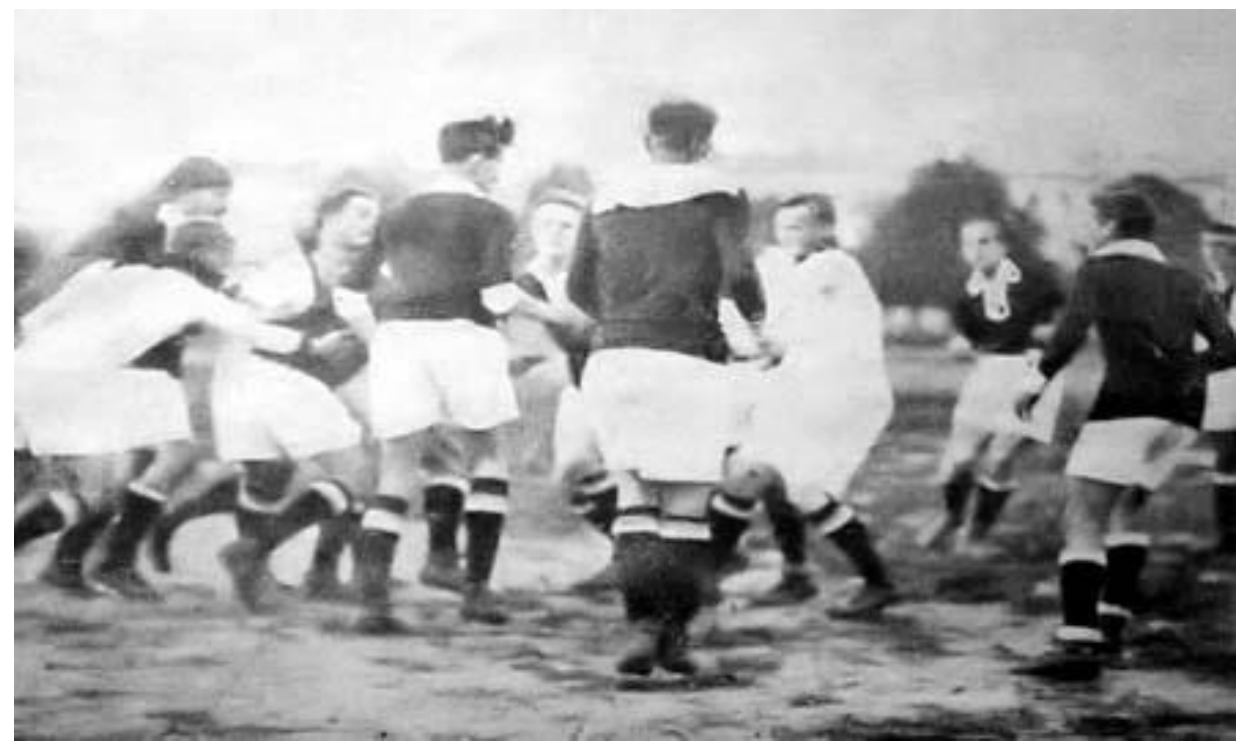

Figure 1. Members of the first rugby match in Ukraine (July 9, 1922).

During the first period of development rugby as a separate kind of sport, it was not extremely popular among the general population in Ukraine.

Therefore, the growing popularity of rugby did not begin with the capital cities, which were Kiev and Kharkov.

The gradual increase in the popularity of rugby began with the regional center, located on the shores of the Black Sea, and a little from the city of Odessa.

After unsuccessful attempts to revive rugby in the late 30 s and 40 s, the oval ball returned to the stadiums of Ukraine in the 60s. The first rugby teams were created on the basis of student sports clubs and sports societies in Kiev, Dnepropetrovsk and Odessa.

In the summer of 1963, the staff of the Kiev Polytechnic Institute took part in the rugby championship in Russia, and the Ukrainian team «Avangard» took part in the championship of the All-Union Trade Union in Tbilisi. The following year, the first Ukrainian team tournament took place in Dnepropetrovsk, in which the 
teams from Kiev, Dnepropetrovsk, Odessa and Tbilisi played. The winner was the capital Dynamo, which three years later will play in the USSR debut championship.

In parallel with the primacy of the Soviet Union, the Ukrainian Championship was also played. Until the 70s, «Dynamo» was the strongest team in Ukraine. Later, the title of the best team is alternately disputed by the capital's "Aviator» and «KPI». The competition in Kiev at that time was «Falcon» (Lvov), "Press" (Dnipropetrovsk), «Polytechnic» (Odessa), as well as other representatives of Kiev: «KIIGA» and «Builder».

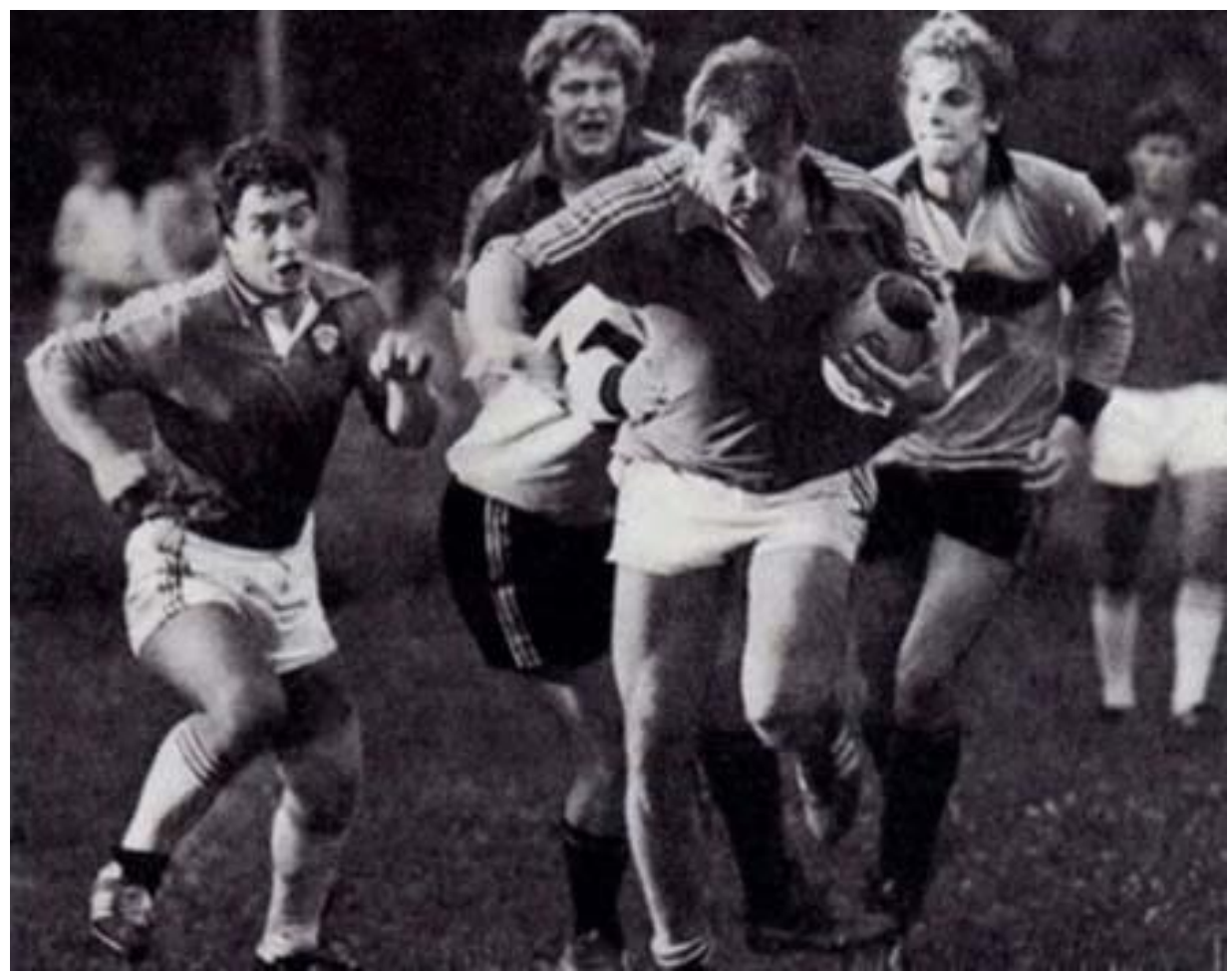

Figure 2. The moment of final game (championship of Ukraine, 1963).

However, from 1965 to the beginning of the 21st century, rugby teams from Kiev invariably became the champions. And only in the 2005 season the Kharkov "OLYMPUS" managed to break off this hegemony.

All Ukrainian Socialistic Republic Rugby Champions:

- «AVIATOR» (Kiev) - 17 times (1970-1974, 1977, 1978, 1980-1987, 1989, 1990);

- «DYNAMO» (Kiev) - 5 times $(1965,1966,1967,1968,1969)$; 
- «POLYTECHNIC» (Kiev) - 5 times $(1975,1976,1979,1988,1991)$.

The first champion of the Ukraine as independent state in 1992 was the «Polytechnic» from Kiev, which held gold medals until the 1797. But starting from 1997 to 2004, another metropolitan team broke out into the leaders of domestic rugby - the «Argo» which was also training in Kiev.

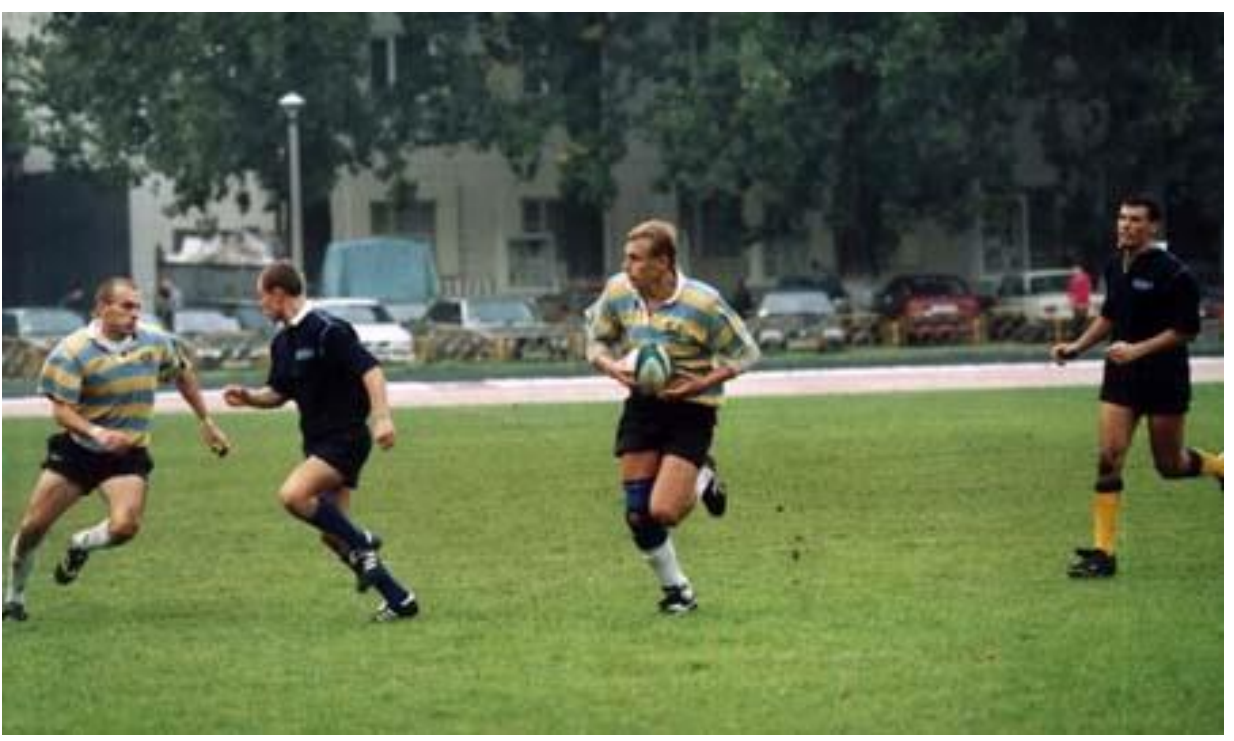

Figure 3. Metropolitan rugby team «Argo» in the crucial match.

Starting from the season 2005 to the present day the best club in Ukraine is «OLYMPUS». In the recent history of the national championship, the rugby team from the Kharkov had 10 victories in the state championship. But only in 2007 the championship winner became the team «CREDO» from Odessa.

All Rugby Champions of the independent Ukraine:

- «OLYMPUS» (Kharkov) - 10 times (2005, 2006, 2007/2008, 2008/2009, 2009-2017);

- «ARGO» (Kiev) - 8 times (1997-2004);

- «POLYTECHNIC» (Kiev) - 6 times (1992-1994, 1994/1995, 1995/1996, 1996/1997);

- «CREDO» (Odessa) - 1 time (2007).

Thus, Odessa, as one of the most important centers for the development of rugby in Ukraine, does not lose its importance over time to maintain the popularity of this sport. 


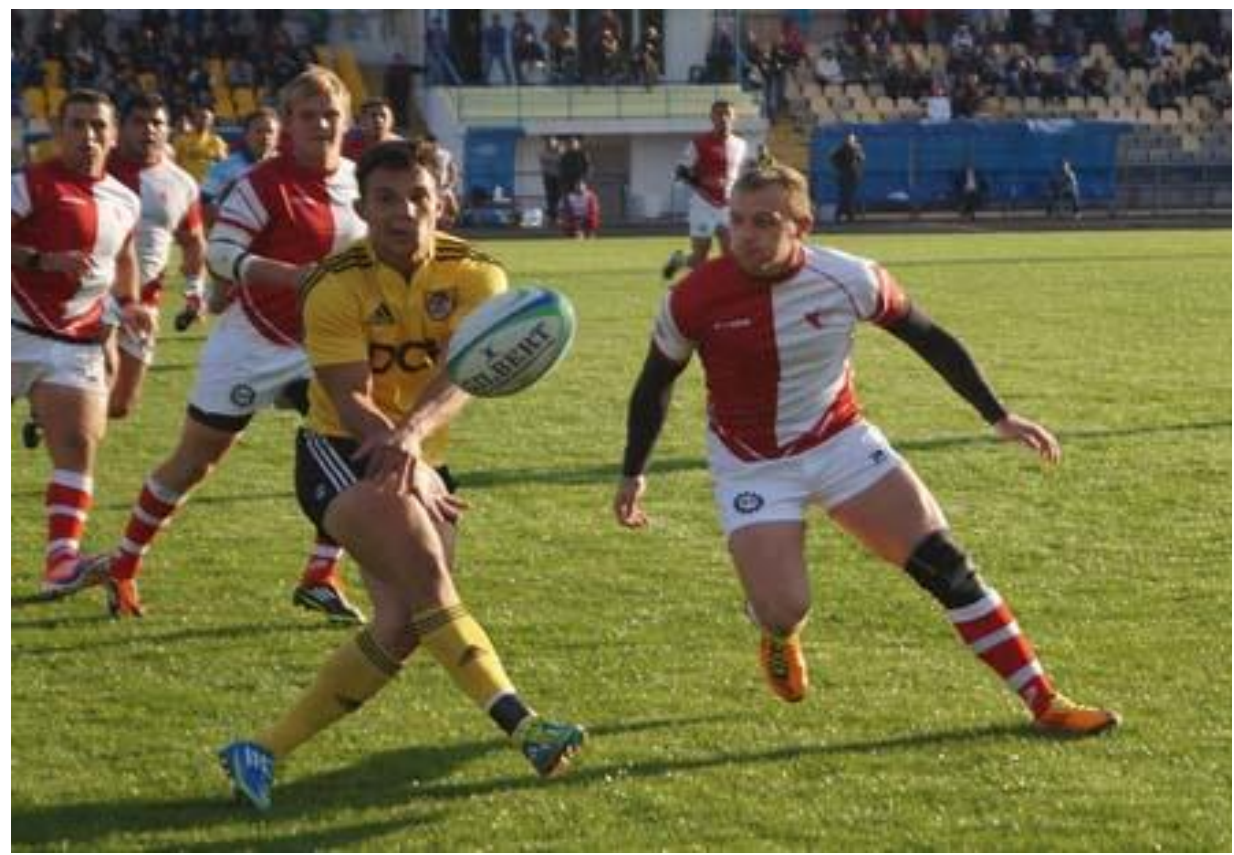

Figure 4. Championship leader team attack moment.

Today in the championship of Ukraine there are 16 teams divided into two divisions: Super League and Major League.

For several seasons, gold medals in the elite category have been played in fulltime confrontation by «OLYMPUS» and «CREDO».

The teams «SOKOL» from Lvov, the «ANTARESs» and «POLYTECHNIC» from Kiev, as well as the rugby club «KHMELNITSKY» from the city of the same name, are actively fighting for the bronze.

In the major league, the degree of struggle for prizes is even higher.

Such rugby teams as «TECHAS» from Kharkov, «ROLAND» from IvanoFrankovsk, «AVIATOR» from Kiev, the team of Raven region, as well as «POLYTECHNIC» and «ACADEMY» from Odessa are all teams of approximately the same level, among which there is an obvious there is no favorite.

Therefore, in almost all matches there is a passion, and the results are far from always predictable.

In the pursuit of primacy between these teams there is always a fierce sports struggle, but it never goes beyond the rules established for this sport. 
Despite a fairly high level of competition between teams that are representatives of different regions of Ukraine, there is always a spirit of mutual respect and recognition of each other's achievements between athletes.

This is due to the fact that the international principles of the Olympic movement, proclaimed by international Olympic organizations, are applied in the domestic system of training highly qualified athletes.

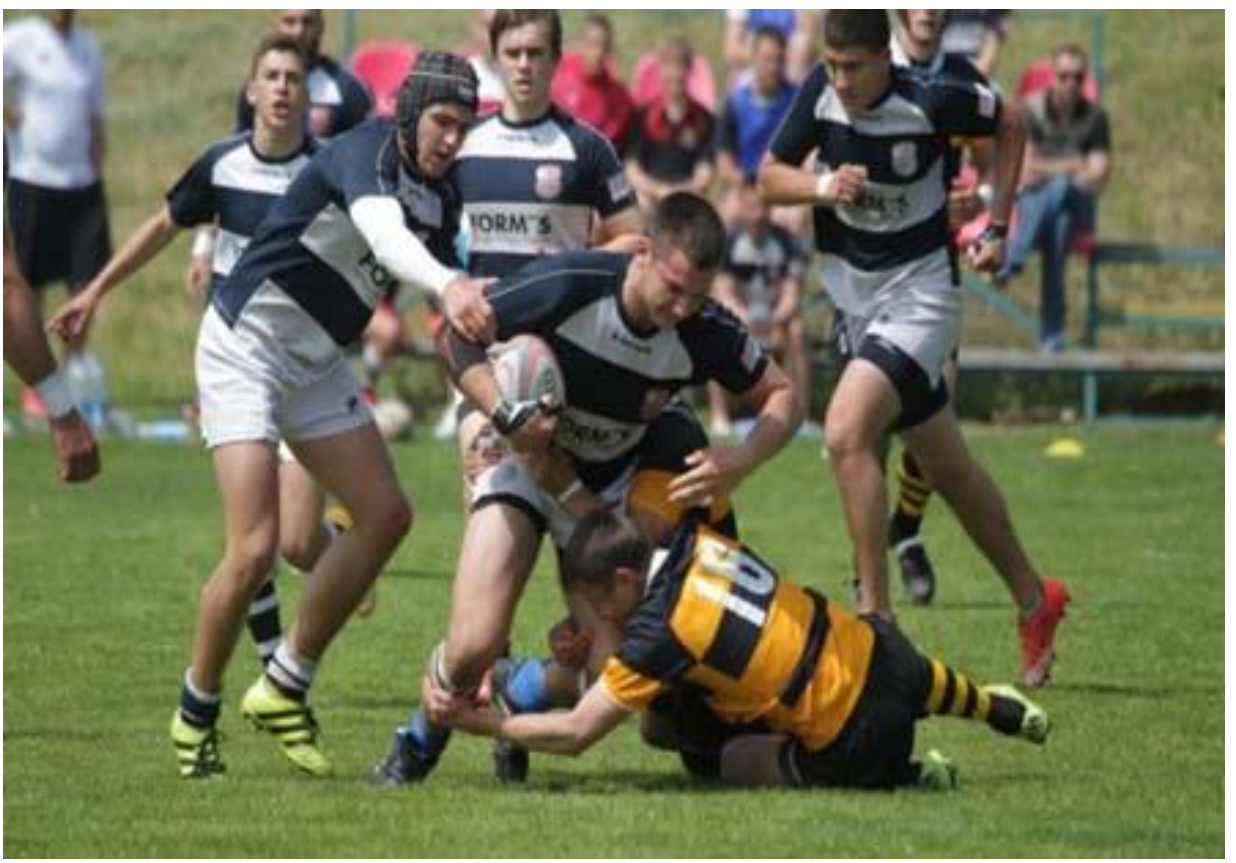

Figure 5. The moment in competition between regional rugby club teams.

Rugby is a contact team sport that arose in the 19th century in England, one of the types of rugby football. The game of rugby has spawned many related sports.

Today in Ukraine there are many clubs and rugby teams for people of different ages. In one of the most numerous rugby clubs, there are about 250 participants.

The main goal of these clubs is: the education of highly qualified players and their own coaching staff, the development of rugby as an important sport and the promotion of a healthy lifestyle, as well as the education of decent and honest members of society.

The main rugby club sets itself the task of creating in the coming years, on the basis of its students, an adult professional team to achieve maximum results in international rugby competitions.

Despite the fact that for a long period of time, part of the population had a prejudice that rugby, as one of the contact sports, is characterized by an increased 
level of aggressiveness and is associated with a high level of sports injuries, people's opinions gradually began to change for the better.

Of course, this was facilitated by the high level of professionalism of the coaching staff and the careful selection of young players who devoted a significant part of the training process to the problems of preventing injury to participants in sports matches.

In the same years, the state system of physical education of different categories of the population was intensively developed and improved in Ukraine. Many scientific institutions have been searching for optimal solutions to pressing problems associated with sports and mass physical education.

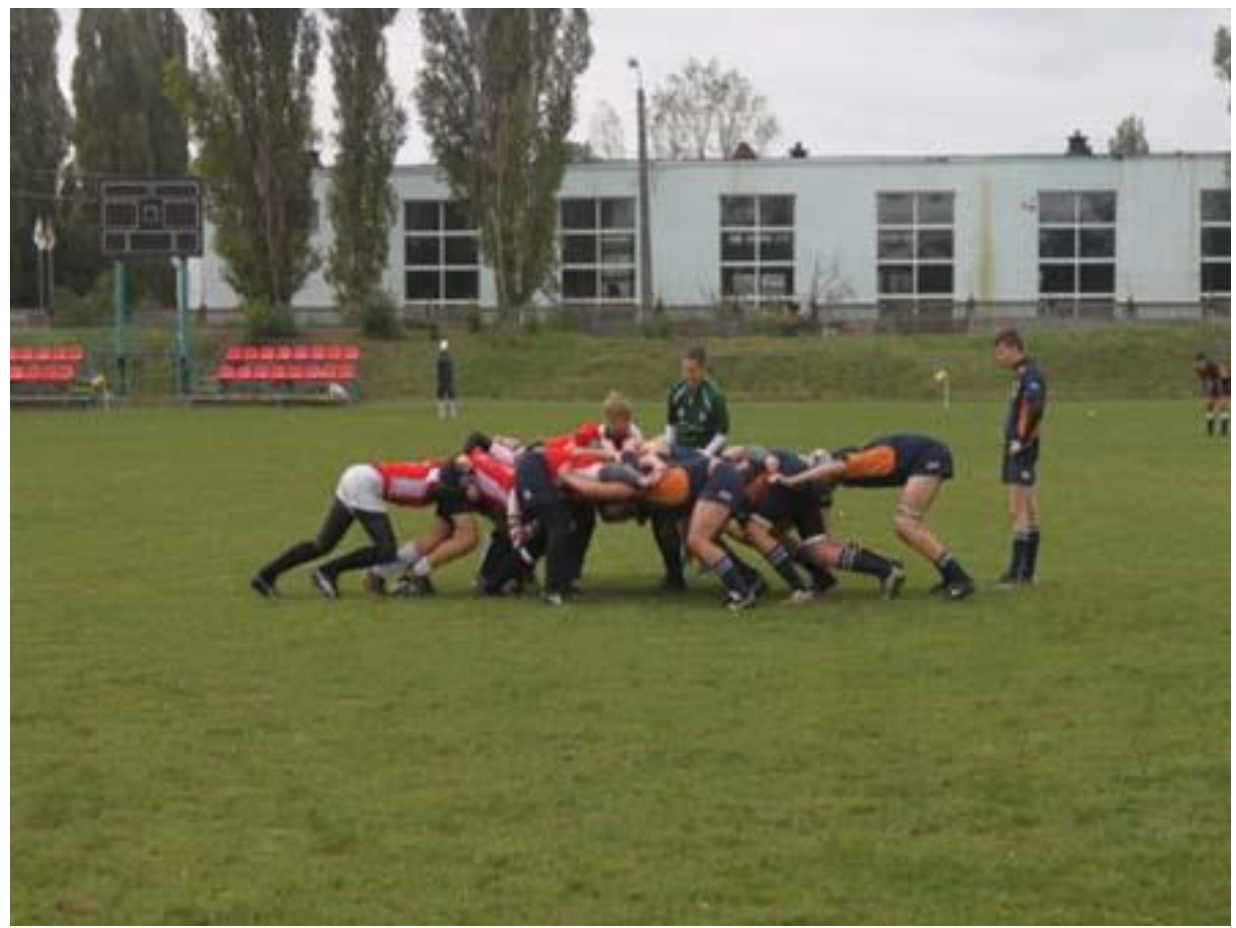

Figure 6. The moment of training in one of the regional rugby clubs.

The team of masters in the rugby club «POLYTECHNIC» (located in Kiev) is the first of the rugby teams, which were created in Ukraine.

The rugby club «POLYTECHNIC» was founded in Kiev in the beginning of 1962.

This year, a group of student enthusiasts organized a rugby section at the department of physical education of the Kiev Polytechnic Institute (now the National Technical University of Ukraine). 
The history of the development of rugby in the Kiev Polytechnic Institute (KPI) is characterized by ups and downs, but there was no case that the team, at least for a short time, ceased to exist.

In addition, in Ukraine there is a specific rugby club "REBELS» which was founded in 2013 and is actively functioning.

This club was organized by former players of the Eger rugby club, which in turn was founded in 1998 by the honoured coach of Ukraine Sergey Guguev.

The peculiarity of this club is that the age of a person who wants to get acquainted with this sport does not matter and there is always a place for him in the team.

This approach to the selection of participants in the training process was recognized as very democratic, since all people living in Ukraine have the legislative right to practice their favorite sport, regardless of age or other circumstances.

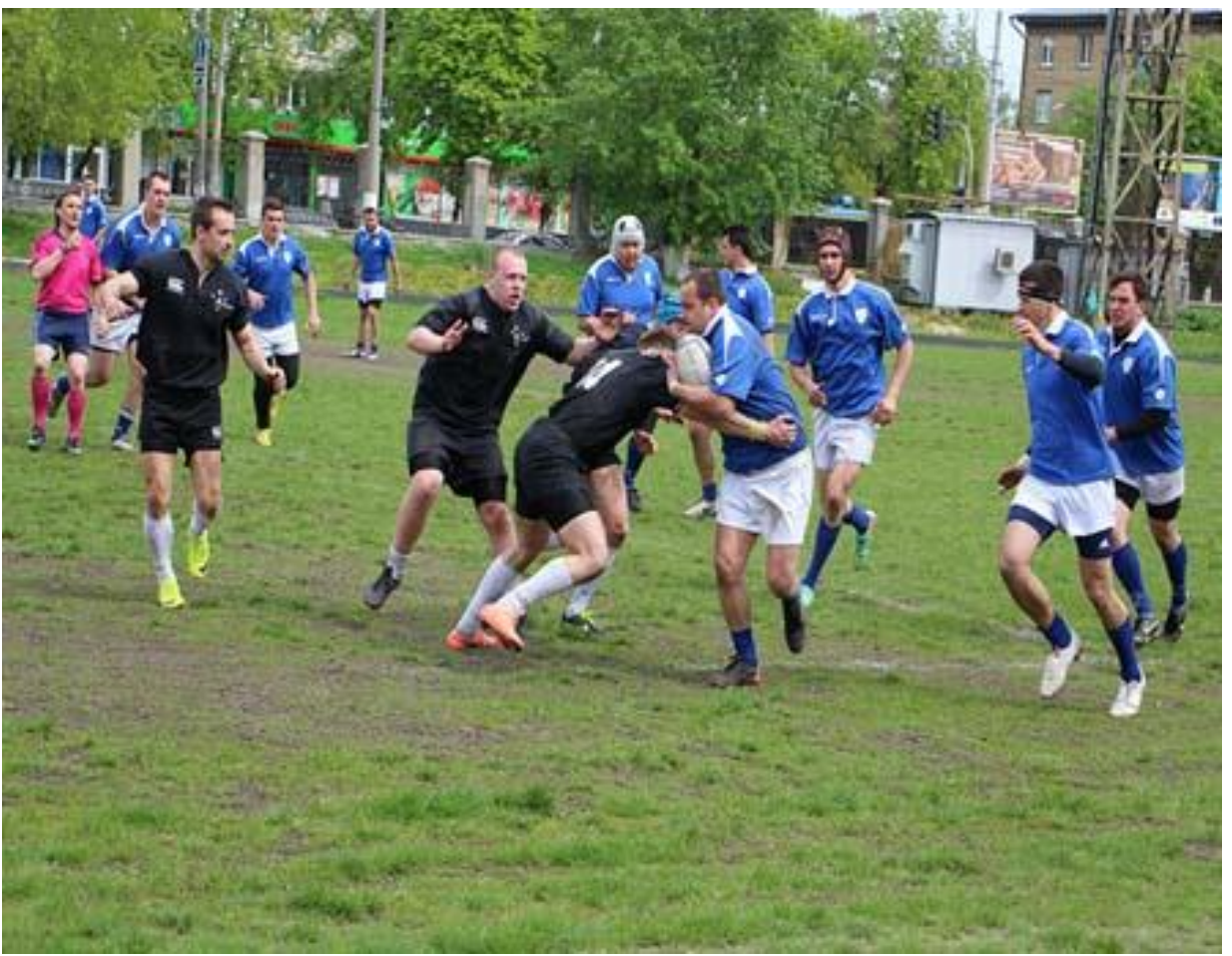

Figure 7. This club trains participants without taking into account their age category.

Another feature of the development of rugby in Ukraine is the fact that some clubs are actively promoting this sport among the fair sex. 
In particular, in the youth rugby club «PEGASUS» there is a place for everyone, because everyone on the team helps each other.

Even girls become more feminine despite the fact that most consider rugby to be purely masculine.

Teams play in friendly matches, tournaments, championships of Kiev and Ukraine.

During the holidays, work does not stop; it is only gaining momentum.

The legislation of Ukraine, as an independent state, provides for the equal rights of men and women in relation to the opportunity to engage in a certain type of sports activity.

In this regard, given the growing interest in rugby among the female population of the country, the statutes of clubs and federations provided for the provision of opportunities for women of different age categories to play rugby, both as part of separate and as part of mixed sports teams.

Therefore, we can confidently say that in Ukraine the process of development of women's rainbow continues, and in the near future sports clubs will have the opportunity to hold regional and interregional rugby championships, including among women's teams.

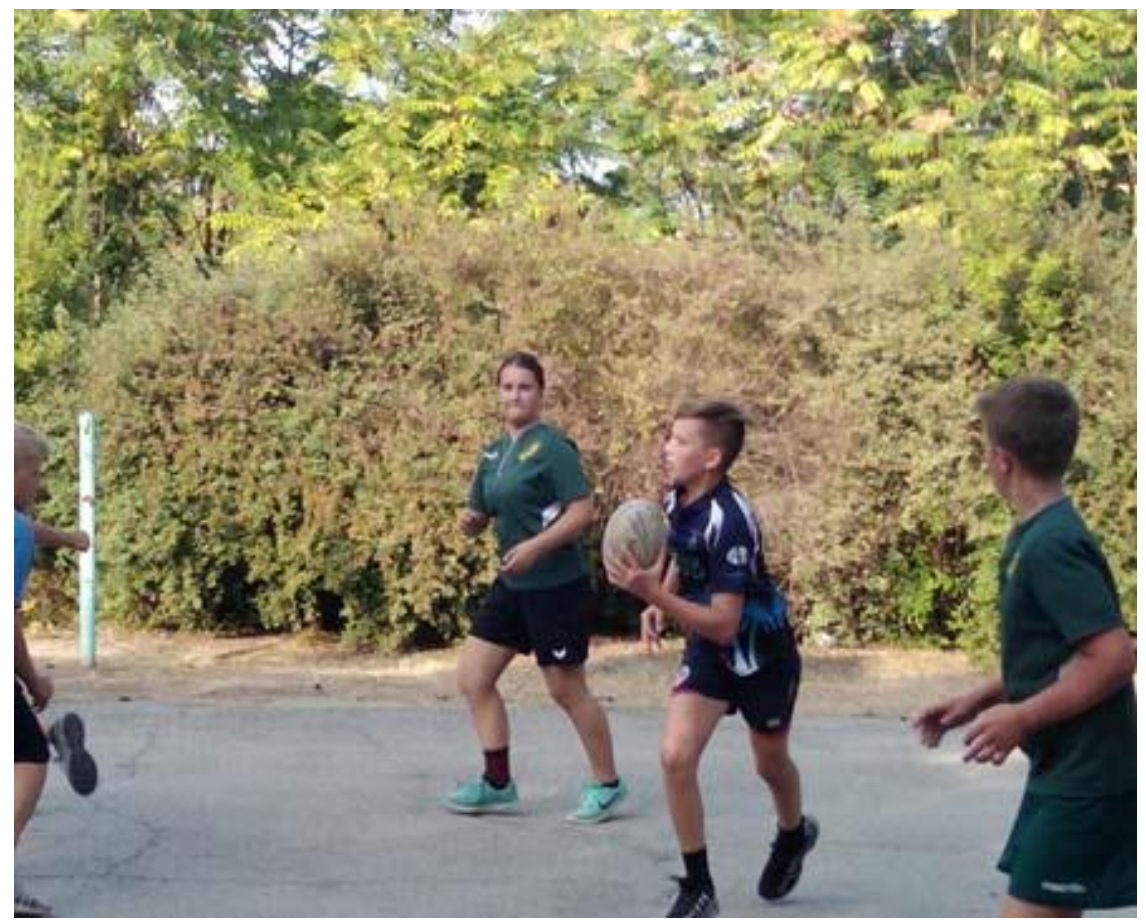

Figure 8. The young girls take part in rugby club training. 
The rugby team «ARGO» was created under the auspices of the country's Olympic Committee and is currently the most titled club in Ukraine in the history of independence.

The club has sections of various ages, and there is also a female team, «ANGELS OF LAW». Age and weight categories do not matter - the main is desire to train and win.

The gender approach in organizing the tinting process in rugby is also extremely important from the point of view of optimizing the algorithm of motor activity of most of the country's population.

This is an important state problem, because the optimization of the motor activity of wide sections of the population leads to the development of such physical qualities of people that are necessary for their effective activity in many areas of industrial and agricultural production.

In addition, the widespread occurrence of rugby among millions of young people can contribute to the creation of the human reserve necessary for the formation of state security forces, such as the armed forces, police, emergency specialists and state security organizations.

Therefore, the development of rugby in Ukraine is an important business for society and is fully supported by the government.

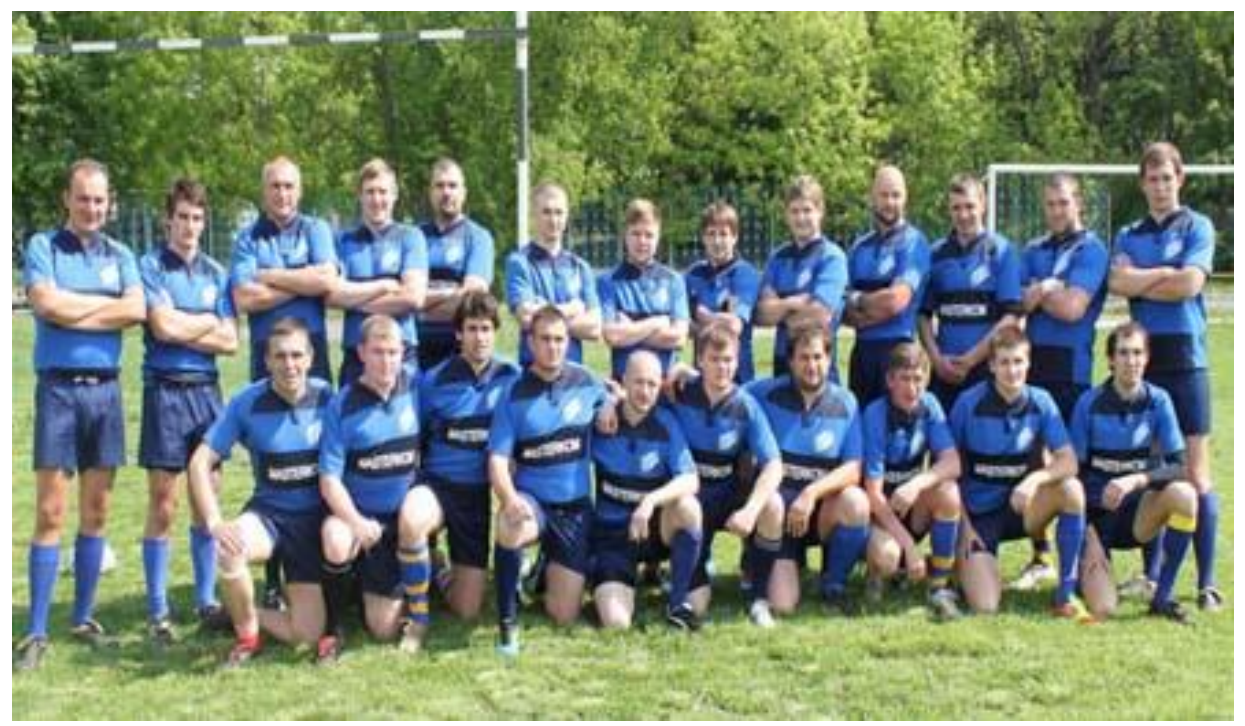

Figure 9. «ARGO» team members with their experienced trainer. 


\title{
REFERENCES
}

1. Basseting R. (2019) Aspects of developing some kinds of sports. Football and Rugby. Effective education, 2019, № 12, p.32 - 51.

2. Braham C.A. Physical Activity and Health across the Lifespan. Perspectives on Health and Exercise / C.A. Braham, C.J. Riddick. - 2019. - 236 p.

3. Brill P. Muscular strength and physical function in rugby / P. Brill // Med. Sci. Sports and Exer. - 2017. - № 15. - P. 132 - 154.

4. Corbin S.V. Physical activity for everyone: What every physical educator should know about promoting lifelong physical activity / C.B. Corbin // Physical Education. - 2012. - № 16. - P. 86 - 134.

5. Ludovici - Connolly A.M. Winning Health Promotion Strategies / A.M. Ludovici Connolly. - Human Kinetics, 2018. - 180 p.

6. Marcus B.H. Motivating People to Be Physically Active (Rugby) / B.H. Marcus, L.A. Forsyth. - [4th edition]. - Human Kinetics, 2015. - 195 p.

7. Physical activity and health in Europe: Evidence for action / edited by N. Cavell, S. Kahlmeier, F. Recopy. - WHO Library Cataloguing in Publication Data, 2016. - 125 p.

8. The world health report: health systems financing: the path to universal coverage. - WHO Library Cataloguing in Publication Data, 2018. - 215 p.

9. Warburton D.E. Health benefits of physical activity in rugby / D.E. Warburton, C.W. Nicole, S.S. Breeding // Canadian Medical Association. - 2016. - № 27 (9). - P. $231-354$.

10. Wilson A.E. Getting the fundamentals of movement: in some kinds of sports. Childcare, Health and Development, 32(5), 123 - 204.

\section{ЗАРОЖДЕНИЕ И РАЗВИТИЕ РЕГБИ В УКРАИНЕ}

\begin{abstract}
АННОТАЦИЯ
В Украине зародилось регби, как специфический вид спорта, в городе Одесса. В 1878 году в Южной Пальмире был основан Одесский британский спортивный клуб, который был организован англичанами - служащими коммерческих фирм, пароходств, а также работниками индоевропейского телеграфа.
\end{abstract}

Ключевые слова: история, регби, Украина

Reccived on 30.04.2020.

Accepted on 01.06.2020. 